Explor Anim Med Res,

Vol.11, Issue - 2, 2021, p. 198-204

DOI : 10.52635/eamr/11.2.198-204
ISSN 2277- 470X (Print), ISSN 2319-247X (Online)

Website: www.animalmedicalresearch.org

Research Article

\title{
ASSESSING THE IMPACT OF SEX-SPECIFIC MICROSATELLITE VARIANTS ON PHENOMICS OF INBRED SWISS ALBINO MICE
}

\author{
B. L. Saini, Pushpendra Kumar*, Amit Kumar, Mitek Tarang, Shweta Sachan, Arnav Mehrotra, Shobhana \\ Kaushal, Anuj Chauhan, Jai Prakash
}

Received 13 April 2021, revised 31 July 2021

\begin{abstract}
An inbred strain limits the segregating variance and provides more power and requires fewer experimental animals to produce good reproducibility. This study was undertaken with the aim to assess the impact of sex of offsprings and sex specific microsatellite variants on performance and fitness traits in $F_{4}$ inbred Swiss albino mice. The phenomics of different performance and fitness traits were estimated on $506 \mathrm{~F}_{4}$ inbred mice population. Two ' $\mathrm{X}$ ' chromosome specific microsatellite loci (DXMit187 and DxMit172) were used for PCR-Microsatellite genotyping of $102 F_{4}$ inbred population. PIC estimates showed that both the loci were informative for the population. In the current population, with the increasing level of "F" a declining trend was observed for Body weight at birth (BWB), Body weight at weaning (BWW), Litter size at weaning (LSW) and Litter weight at weaning $(L W W)$. In $F_{4}$ inbred population, BWW and ABW for males $(17.32 \pm 0.32 \mathrm{~g}$ and 30.81 $\pm 0.31 \mathrm{~g})$ were significantly $(\mathrm{p}<0.05)$ higher than females $(16.39 \pm 0.30 \mathrm{~g}$ and $27.83 \pm 0.28 \mathrm{~g})$. The significant $(\mathrm{p}<0.05)$ impact of sex of offspring on performance traits revealed that less magnitude of inbreeding depression was observed in male as compared to female. There were 3 alleles and 5 genotypes at the DXMit172 locus, and 3 alleles and 4 genotypes at the DXMit187 locus. The highest and lowest allelic frequencies were found at DXMit172 locus for $142(0.422)$ and 154 (0.226) alleles, respectively, and at DXMit187 locus for $126(0.588)$ and $146(0.093)$ alleles, respectively. Genotype $142 / 142$ $(0.382)$ and 154/148 $(0.059)$ had the highest and lowest genotypic frequency at the DXMit172 locus, respectively, and at DXMit187 locus for 126/126 (0.588) and 146/146 (0.039) genotypes, respectively. In the current study, only the DXMit172 loci had significant genotypic associations with fitness traits $(p<0.05)$. The average $F_{\text {IS }}$ based on $X$ - specific microsatellite markers was 0.790 in the $F_{4}$ inbred population. These results indicate that rate of inbreeding depression is more in females than in males.
\end{abstract}

Key words: Swiss albino inbred mice, Performance traits, Inbreeding depression, Genetic characterization, Microsatellite markers, Population genetic parameters.

\section{INTRODUCTION}

The Swiss albino mice, because of their many beneficial attributes, including their small size, short generation interval, high prolificacy and fecundity, low cost of management of breeding colonies, detailed understanding of their biology and genomic resemblance to humans, is recognized as a pre-eminent animal model for biological research (Zheng-Bradley et al. 2010, Yue et al. 2014, Li et al. 2017).

Inbreeding segregates a population into subpopulations, and tends to increase homozygosity among the individuals of a population that leads to a reduction in the mean phenotypic value of performance and fitness traits, known as inbreeding depression (Selvaggi et al. 2010, Danneman et al. 2012). Therefore, genetic monitoring of inbreeding is very important in order to control the inbreeding depression and genetic contamination (Nomura et al. 1984). Microsatellites are considered as an ideal DNA marker for deciphering genetic variability and contamination of genetic resources due to their abundance, random distribution throughout genomes and high degree of polymorphisms (Tautz 1989, Gulcher 2012).

The genetic variances among the individuals of an inbred strain are at the lowest level. Therefore, they limit the noise produced by segregation of genetic variance. 
Inbred strain has a high level of genetic uniformity and stability, making it possible to obtain an identical genotype over a long period of time (Sommer and Ketterling 1994). The only reason for genetic variation between males and females of an inbred strain is sex specific chromosomes. Thus, an inbred strain provides more power and requires fewer experimental animals to produce good reproducibility (Eppig 2007, Casellas 2011, Danneman et al. 2012).

Hence, considering the importance of genetic stability of inbred strain of mice, the present investigation was undertaken with the aim to assess the impact of sex of offsprings and sex chromosomes specific microsatellite variants on performance and fitness traits in $\mathrm{F}_{4}$ inbred Swiss albino mice.

\section{MATERIALS AND METHODS}

\section{Experiment set-up and breeding strategy}

The $\mathrm{F}_{3}$ inbred Swiss albino mice maintained at Laboratory Animal Research (LAR) section of Animal Genetics Division, ICAR- Indian Veterinary Research Institute, Izatnagar, Bareilly (U. P.), India, were used as experimental animal for this study. In order to produce a high fecund inbred strain of Swiss albino mice, the following three criteria were used to select full sib breeding pairs in each generation: (i) apparently healthy full sibs, (ii) minimum adult body weight $\geq 30 \mathrm{~g}$ and (iii) LSB $\geq 8$. The 90 full sib mating pairs of $F_{3}$ inbred Swiss albino mice were selected at the age of 85-90 days and full sib mating was practiced to produce $F_{4}$ inbred generations of mice. The selected breeding pairs were allowed ad libitum access to food and water. Each full sib pairs were kept in separate cages for breeding in order to produce offsprings of next inbred generation. After 18-21 days of setting up of breeding, offsprings of inbred generation were started coming in all the cages. Sexing and weaning of offspring were done at 28 days and male and female mice were placed in separate new cages. After sexing, offsprings identification was facilitated by using picric stain to mark each male and female (Leclercq and

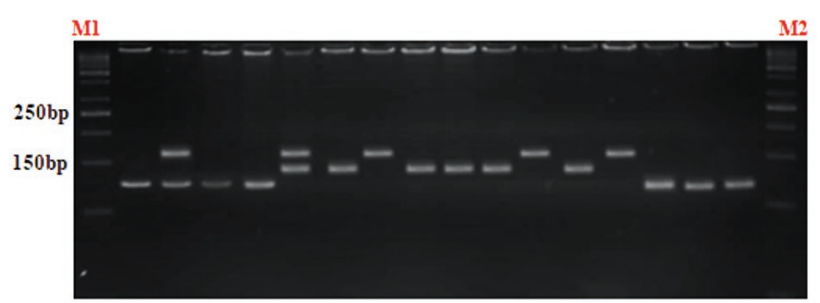

Fig. 1. DXMit172 microsatellite allele profiling using ultra resolution agarose in Swiss Albino mice.

(Lane M1 and M2: 50 bp marker; Lanes 1-17: resolved PCR products).
Rozenfeld 2001). These mice were reared under similar feeding and management conditions throughout the experimental period.

\section{Measurement of phenomics of inbred mice}

The phenomics of different performance traits i.e., Body weight at birth (BWB), Body weight at weaning (BWW) and Adult body weight (ABW) and fitness traits i.e., Litter size at birth (LSB), Litter weight at birth (LWB), Litter size at weaning (LSW) and Litter weight at weaning $(\mathrm{LWW})$ were estimated on $506 \mathrm{~F}_{4}$ inbred mice population. BWB, BWW and $\mathrm{ABW}$ were recorded in grams (g) at age of 0, 28 and 85-90 days respectively.

\section{Tissue collection and DNA Extraction}

Genomic DNA was extracted from the tail tissue (1$1.5 \mathrm{~cm}$ ) of 102 adult $\mathrm{F}_{4}$ inbred mice using DNA Isolation kit (Qiagen DNeasy Blood \& Tissue Kit) as per the manufacturer's instructions. A spectrophotometer and $0.8 \%$ agarose gel electrophoresis were used to determine DNA concentration and purity (A260/A280 ratio) for each sample. The calibrated DNA samples were kept at $-20^{\circ} \mathrm{C}$ until they were analysed further.

\section{Detection of genetic variability in $F_{4}$ inbred mice using PCR-microsatellite}

For genotyping at different microsatellite loci, $102 \mathrm{~F}_{4}$ inbred female mice were randomly selected. Two ' $\mathrm{X}$ ' chromosome specific microsatellite loci (DXMit187 and DxMit172) were used in the present study. Detailed information about each microsatellite locus along with primer sequence, annealing temperature, and amplicon size is given in Table 1. Gradient PCR was used to identify the optimal annealing temperature for each primer. The PCR reaction mixture and standard PCR protocol for microsatellite loci are shown in Table 2 and 3, respectively. All PCR reactions were carried out using thermo cycler (Bio-Rad, USA).

For microsatellite genotyping, the amplified products were first run on $2.5 \%(\mathrm{w} / \mathrm{v})$ agarose gel electrophoresis

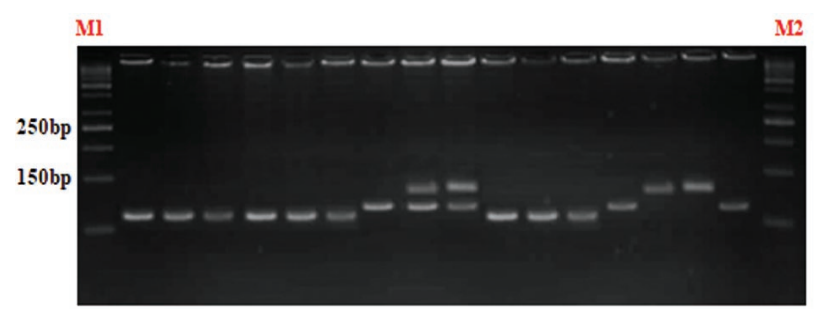

Fig. 2. DXMit187 microsatellite allele profiling using ultra resolution agarose in Swiss Albino mice.

(Lane M1 and M2: 50 bp marker; Lanes 1-17: resolved PCR products). 
Assessing the impact of sex-specific microsatellite variants on phenomics...

Table 1. Details of microsatellite loci along with primer sequence, annealing temperature (AT) and amplicon size (AS) of each microsatellite locus.

\begin{tabular}{|c|c|c|c|c|c|c|}
\hline $\begin{array}{l}\text { Sl. } \\
\text { No }\end{array}$ & $\begin{array}{l}\text { Microsatellite } \\
\text { Loci }\end{array}$ & $\begin{array}{l}\text { Chr } \\
\text { No }\end{array}$ & Primer sequence (5' ? 3') & $\begin{array}{l}* \mathrm{Ta} \\
\left({ }^{\circ} \mathbf{C}\right)\end{array}$ & $\begin{array}{l}* \mathbf{K} \\
(\mathbf{b p})\end{array}$ & Reference \\
\hline \multirow[t]{2}{*}{1} & DXMit187 & $\mathrm{X}$ & F: AAACACACCAAAAGAAGGTTTTG & 58.5 & $116-$ & Zhang et al. (2007) \\
\hline & & & R: GTGAGTTCAAGGTGACTAAACGG & & 132 & \\
\hline \multirow[t]{2}{*}{2} & DxMit172 & $\mathrm{X}$ & F: TACCACAGTTTGAATAAAGATGTGTG & 58 & $129-$ & Zuo et al. (2012) \\
\hline & & & R: GAAGAAACCATGACTCCTCTTTG & & 148 & \\
\hline
\end{tabular}

*Ta- Annealing temperature; **K- Previously reported range of allele size in bp.

to check for their amplification. The products were then resolved on ultra-high-resolution agarose (4\%; at 50-75 $\mathrm{V}$; for 3-6 h)) to differentiate alleles as per their length (in base pairs). Visualizing of each gel was done under Gel Doc (Genesnap, Syngene) system and allele size was determined by using Gel Analyzer (2010) software.

\section{Statistical analysis}

POPGENE 32 (Yeh et al. 1999) software was used to estimate " $\mathrm{H}_{\mathrm{o}}$ " and " $\mathrm{H}_{\mathrm{e}}$ ", allele frequencies, observed number of alleles per locus, effective number of alleles, polymorphic information content (PIC), allelic diversity, Wright's F-statistic $\left(\mathrm{F}_{\mathrm{IS}}\right)$, and Hardy Weinberg equilibrium. The $\mathrm{F}_{\mathrm{IS}}$ was calculated as deviation of the " $\mathrm{H}_{\mathrm{o}}$ " of an individual relative to the " $\mathrm{H}_{\mathrm{e}}$ " under random mating (Lukas and Donald 2002) which was derived as: $\mathrm{F}_{\mathrm{IS}}=1-(\mathrm{Ho} / \mathrm{He})$,

Where: $\mathrm{F}_{\mathrm{IS}}$ : coefficient of inbreeding; $\mathrm{H}_{\mathrm{o}}$ : observed frequency of heterozygous individuals; $\mathrm{H}_{e}$ : expected frequency of heterozygous individuals in the population.

Fixed effects of sex of offsprings on performance traits of $\mathrm{F}_{4}$ inbred Swiss albino mice were computed using

Table 2. PCR reaction mixture for different microsatellite loci.

\begin{tabular}{clc}
\hline $\begin{array}{l}\text { Sl. } \\
\text { No. }\end{array}$ & Reaction component & $\begin{array}{c}\text { Amount 1X } \\
(\mathbf{2 5} \boldsymbol{\mu l})\end{array}$ \\
\hline 1. & Dream Taq green buffer & $2.5 \mu \mathrm{l}$ \\
2. & Forward Primer $(10 \mathrm{pmol} / \mu \mathrm{l})$ & $1.0 \mu \mathrm{l}$ \\
3. & Reverse Primer $(10 \mathrm{pmol} / \mu \mathrm{l})$ & $1.0 \mu \mathrm{l}$ \\
4. & dNTPs mix $(10 \mathrm{mM})$ & $0.5 \mu \mathrm{l}$ \\
5. & Taq DNA polymerase $(5 \mathrm{U} / \mu \mathrm{l})$ & $0.2 \mu \mathrm{l}$ \\
6. & Genomic DNA & $2.0 \mu \mathrm{l}$ \\
7. & Nuclease free water & $17.8 \mu \mathrm{l}$ \\
\hline
\end{tabular}

PROC GLM module of SAS 9.3. Effect of inbreeding on phenotypic traits was also estimated. Effect of allelic variants of microsatellites was determined on performance and fitness traits through PROC GLM module of SAS 9.3 using following model: $y i j=\mu+$ gi + eij,

Where, $y i j=$ observation for performance and fitness trait on $\mathrm{j}^{\text {th }}$ mouse in $\mathrm{i}^{\text {th }}$ genotype; $\mu=$ overall mean; gi $=$ effect of $\mathrm{i}^{\text {th }}$ genotype; eij $=$ random error $\sim$ NID $\left(0, \mathrm{e}^{2}\right)$.

\section{RESULTS AND DISCUSSION}

Phenotypic characterization of $F_{4}$ inbred Swiss albino mice

In the studied $\mathrm{F}_{4}$ population, performance traits such as BWB, BWW, and ABW were found to be $1.58 \pm 0.01 \mathrm{~g}$, $16.90 \pm 0.22 \mathrm{~g}$ and $29.42 \pm 0.23 \mathrm{~g}$, respectively, while fitness traits such as LSB, LWB, LSW, and LWW were found to be $6.60 \pm 0.14,8.05 \pm 0.54 \mathrm{~g}, 6.04 \pm 0.14$ and $86.74 \pm 5.1 \mathrm{~g}$, respectively. These mean estimates of performance and fitness traits were in declining trend with the increasing level of "F" (Tarang 2018, Kaushal 2019). These findings revealed that effect of inbreeding was detrimental on performance and fitness traits.

Our results are in concordance with findings of White (1972), who observed that increasing inbreeding level reduced postnatal maternal output and significantly reduced birth weight and weight at 12, 21, 42, and 56 days in the litter. Holt et al. (2005) also noticed marginal inbreeding depression on body weight at 21 and 42 days. Similar declining trend was noticed in the mean estimates of BWB, LSB, LWB, LSW and LWW on characterization of $\mathrm{F}_{0}$ and $\mathrm{F}_{1}$ generation of Swiss albino mice (Tarang 2018). Kaushal (2019) characterized $F_{2}$ and $F_{3}$ inbred mice population and inbreeding depression was noticed in BWB, BWW, ABW and LSB. When compared with the result of Tarang (2018) and Kaushal (2019), it revealed that the majority of performance and fitness traits 
Table 3. Standardized PCR protocol for various fragments.

\begin{tabular}{|c|c|c|c|c|}
\hline $\begin{array}{l}\text { Sl. } \\
\text { No. }\end{array}$ & Steps & $\begin{array}{l}\text { Temperature } \\
\left({ }^{\circ} \mathrm{C}\right)\end{array}$ & Time & \\
\hline 1. & Initial denaturation & $95^{\circ} \mathrm{C}$ & $5 \mathrm{~min}$ & \multirow{6}{*}{40} \\
\hline \multirow[t]{3}{*}{2.} & Denaturation & $95^{\circ} \mathrm{C}$ & $1 \mathrm{~min}$ & \\
\hline & Annealing & $58.0-85.5^{\circ} \mathrm{C}^{*}$ & $45 \mathrm{~s}$ & \\
\hline & Extension & $72^{\circ} \mathrm{C}$ & $1 \mathrm{~min}$ & \\
\hline 3. & Final extension & $72^{\circ} \mathrm{C}$ & $5 \mathrm{~min}$ & \\
\hline 4. & Storage & $4^{\circ} \mathrm{C}$ & - & \\
\hline
\end{tabular}

* Standardized annealing temperature as per primer loci (Ref. Table 1 for Ta).

were declining with each successive generation, but the magnitude of inbreeding depression between two consecutive generations was also decreasing, indicating that the rate of inbreeding was decreasing.

The impact of sex of offspring on performance traits revealed that mean estimates of $\mathrm{BWW}$ and $\mathrm{ABW}$ in $\mathrm{F}_{4}$ inbred mice was higher in males than in females (Table 4). These findings revealed that less magnitude of inbreeding depression was observed in BWW and ABW of male as compared to that of female. When the "F" was increased by $1 \%$, BWW was decreased by $0.06 \mathrm{~g}$ in males and $0.164 \mathrm{~g}$ in females. The similar pattern of mean estimates of BWW and $\mathrm{ABW}$ for male and female were also noticed by Tarang (2018) in $\mathrm{F}_{1}$ and by Kaushal (2019) $\mathrm{F}_{2}$ inbred mice population. These studies showed that mean estimate of BWW was varying in very narrow range as the inbreeding coefficient increased from $\mathrm{F}_{1}$ inbred to $\mathrm{F}_{4}$ inbred mice populations. This may be attributed to the LSB consistently declining, resulting in a better or less competitive climate for the nourishment of young ones. However, as the inbreeding coefficient increased, the $\mathrm{ABW}$ of the $\mathrm{F}_{1}$ inbred to $\mathrm{F}_{4}$ inbred mice population decreased. It might be attributable to late gene expression as an impact of inbreeding.

Genetic characterization of $F_{4}$ inbred mice

In the present study, both the microsatellite loci were found to be polymorphic. There were 3 alleles (154 bp,

Table 4. Effect of sex on $B W W$ and $A B W$ in $F_{4}$ and $F_{5}$ inbred population of Swiss albino mice.

\begin{tabular}{lll}
\hline Sex & BWW $($ Mean \pm SE) $(\mathbf{N})$ & ABW $($ Mean \pm SE) $(\mathbf{N})$ \\
\hline Male & $17.32^{\mathrm{a}} \pm 0.32(251)$ & $30.81^{\mathrm{a}} \pm 0.31(242)$ \\
Female & $16.39^{\mathrm{b}} \pm 0.30(212)$ & $27.83^{\mathrm{b}} \pm 0.28(212)$ \\
\hline
\end{tabular}

148 bp and 142 bp and 5 genotypes (154/154, 154/148, $154 / 142,148 / 148$ and 142/142) at the DXMit172 locus, and 3 (146 bp, $134 \mathrm{bp}$ and $126 \mathrm{bp}$ ) alleles and 4 (146/ $146,146 / 134,134 / 134$ and 126/126) genotypes at the DXMit187 locus. The highest and lowest allelic frequencies found at DXMit172 locus were for 142 (0.422) and $154(0.226)$ alleles, respectively, and at DXMit 187 locus for $126(0.588)$ and $146(0.093)$ alleles, respectively (Table 5). Genotype 142/142 (0.382) and $154 / 148(0.382)$ had the highest and lowest genotypic frequency at the DXMit172 locus, respectively, and at DXMit187 locus for 126/126 (0.588) and 146/146(0.039) genotypes, respectively (Table 6). Zuo et al. (2012), on the other hand, reported 148 bp alleles at DXMit172 locus in the C57BL/6J (B6) and 129 mouse strains. Zhang et al. (2007) found allele $128 \mathrm{bp}$ for DXMit187 locus in $\mathrm{BALB} / \mathrm{c}, \mathrm{C} 57 \mathrm{BL} / 6$, and all four strains of $\mathrm{KM}$ mice (A1, $\mathrm{T} 2, \mathrm{~N} 2$, and N4). The variation in allelic size could be attributed to different levels of inbreeding and different types of mouse strains. Zhang et al. (2007) observed that DXMit187 locus showed homozygosity in BALB/c, C57BL/6, and all four strains of KM mice (A1, T2, N2, and N4). The representative images of gel electrophoresis of a microsatellite locus on $4 \%$ agarose gel are shown in Fig. 1 and Fig. 2 respectively.

PIC estimates showed that both the loci were moderately informative for the studied population. The standard errors of allelic and genotypic frequencies were within acceptable limits (Table 6). Allelic diversity values were also found to be varying from moderate to high in range. Chi square test revealed that all the loci were significantly deviated from HWE at $p<0.05$. These results were in agreement with the findings of Tarang (2018) and Kaushal (2019). The " $\mathrm{H}_{\mathrm{o}}$ " for DXMit172 and DXMit187 loci was 0.137 and 0.108 , respectively, while the " $\mathrm{H}_{\mathrm{e}}$ " was 0.647 and 0.544 respectively (Table 7). The number of observed alleles $\left(\mathrm{N}_{\mathrm{a}}\right)$ per locus was 3 , while the number of effective alleles $\left(\mathrm{N}_{\mathrm{e}}\right)$ varied from 2.192 (DXMit187) to 2.832. (DXMit172). The $\mathrm{F}_{\text {IS }}$ estimate was ranged from 0.788 (DXMit172) to 0.802 (DXMit187) per locus (Table 7). The average inbreeding coefficient based on X-chromosome specific microsatellite markers was positive and estimated as 0.790 in the $F_{4}$ inbred population.

\section{Association statistics of microsatellite variants with performance and fitness traits}

In the present population, the mean estimate of BWW, ABW, LSB, LWB, LSW and LWW for DXMit172 locus was $16.76 \pm 0.41 \mathrm{~g}, 28.22 \pm 0.39 \mathrm{~g}, 6.00 \pm 0.20,9.22 \pm 0.31 \mathrm{~g}$, $5.21 \pm 0.17$ and $83.22 \pm 2.76 \mathrm{~g}$ respectively (Table 8 ). The 
Assessing the impact of sex-specific microsatellite variants on phenomics...

Table 5. Allelic frequency distribution at DXMit172 microsatellite loci for $\mathrm{F}_{4}$ inbred mice population.

\begin{tabular}{llllccc}
\hline Locus & Allele & N & Frequency & Standard Error & $\mathbf{9 5 \%}$ & Confidence Limits \\
\hline \multirow{5}{*}{ DXMit172 } & 154 & 46 & 0.226 & 0.037 & 0.147 & 0.304 \\
& 148 & 72 & 0.353 & 0.046 & 0.265 & 0.446 \\
& 142 & 86 & 0.422 & 0.047 & 0.328 & 0.520 \\
DXMit187 & 146 & 19 & 0.093 & 0.024 & 0.049 & 0.142 \\
& 134 & 65 & 0.319 & 0.043 & 0.230 & 0.407 \\
& 126 & 120 & 0.588 & 0.049 & 0.490 & 0.677 \\
\hline
\end{tabular}

Table 6. Genotypic frequency distribution at DXMit172 and DXMit187 microsatellite loci for $\mathrm{F}_{4}$ inbred mice population.

\begin{tabular}{lllcclcc}
\hline Locus & Genotype & $\mathbf{N}$ & Frequency & HWD coefficient & SE & 95\% & Confidence Limits \\
\hline \multirow{2}{*}{ DXMit172 } & $154 / 154$ & 16 & 0.157 & 0.106 & 0.022 & 0.061 & 0.147 \\
& $154 / 148$ & 6 & 0.059 & 0.050 & 0.015 & 0.021 & 0.080 \\
& $154 / 142$ & 8 & 0.078 & 0.056 & 0.017 & 0.021 & 0.087 \\
& $148 / 148$ & 33 & 0.324 & 0.199 & 0.017 & 0.162 & 0.227 \\
& $142 / 142$ & 39 & 0.382 & 0.205 & 0.015 & 0.168 & 0.230 \\
& $146 / 146$ & 4 & 0.039 & 0.031 & 0.016 & 0.002 & 0.063 \\
DXMit187 & $146 / 134$ & 11 & 0.108 & -0.024 & 0.012 & -0.048 & -0.002 \\
& $134 / 134$ & 27 & 0.265 & 0.163 & 0.020 & 0.123 & 0.198 \\
& $126 / 126$ & 60 & 0.588 & 0.242 & 0.009 & 0.219 & 0.250 \\
\hline
\end{tabular}

Table 7. Summary statistics of genetic variation and genetic parameters for all microsatellite loci in $F_{4}$ inbred population.

\begin{tabular}{lccccccc}
\hline Locus & $\begin{array}{l}\text { Sample } \\
\text { Size (N) }\end{array}$ & $\begin{array}{l}\text { Observed } \\
\text { alleles }\left(\mathbf{N}_{\mathbf{a}}\right)\end{array}$ & $\begin{array}{l}\text { Effective } \\
\text { alleles }\left(\mathbf{N}_{\mathbf{e}}\right)\end{array}$ & $\begin{array}{l}\text { Observed } \\
\text { heterozygosity } \\
\left(\mathbf{H}_{\mathbf{o}}\right)\end{array}$ & $\begin{array}{l}\text { Expected } \\
\text { heterozygosity } \\
\left(\mathbf{H}_{\mathbf{e}}\right)\end{array}$ & $\begin{array}{l}\text { Shannon's } \\
\text { Inform.index } \\
(\mathbf{I})\end{array}$ & $\mathbf{F}_{\text {Is }}$ \\
\hline DXMit172 & 204 & 3.000 & 2.832 & 0.137 & 0.647 & 1.068 & 0.788 \\
DXMit187 & 204 & 3.000 & 2.192 & 0.108 & 0.544 & 0.898 & 0.802 \\
Mean & & 3.000 & 2.771 & 0.196 & 0.631 & 1.087 & 0.790 \\
SD & & 0.497 & 0.448 & 0.061 & 0.057 & 0.143 & \\
\hline
\end{tabular}

significant $(\mathrm{p}<0.05)$ genotypic associations were observed with fitness traits while non-significant $(\mathrm{p}<0.05)$ genotypic associations were found with performance traits. The results showed that genotype 154/142 had the highest mean estimates of LSB (7.38 \pm 0.92$)$ and LWB $(11.12 \pm 1.51 \mathrm{~g})$, while genotype $142 / 142$ had the highest mean estimates of LSW $(5.73 \pm 0.26)$ and LWW $(93.90 \pm 3.86 \mathrm{~g})$. The interaction statistics revealed that genotypic associations of DXMit187 locus with performance and fitness traits in the $\mathrm{F}_{4}$ inbred population were non-significant $(\mathrm{p}<0.05)$. For the DXMit187 locus, the mean estimates of BWW, ABW, LSB, LWB, LSW, and LWW were $16.76 \pm 0.4 \mathrm{~g}, 28.22 \pm 0.39 \mathrm{~g}, 6.00 \pm 0.20$, $9.22 \pm 0.3 \mathrm{~g}, 5.21 \pm 0.17$, and $83.22 \pm 2.76 \mathrm{~g}$, respectively (Table 8).

\section{CONCLUSION}

The results of present investigation revealed that the magnitude of inbreeding depression on performance and 
Table 8. Association statistics of DXMit172 and DXMit187 microsatellite loci with performance (WW and ABW) and fitness (LSB, LWB, LSW and LWW) traits of $\mathrm{F}_{4}$ inbred Swiss albino mice (Mean \pm SE).

\begin{tabular}{|c|c|c|c|c|c|c|c|}
\hline Locus & Genotype & BWW & $\mathbf{A B W}$ & LSB & LWB & LSW & LWW \\
\hline & & & & & & & \\
\hline \multirow{6}{*}{ DXMit172 } & $\begin{array}{c}154 / 154 \\
(16)\end{array}$ & $\begin{array}{c}18.22^{\mathrm{a}} \pm 0.99 \\
(16)\end{array}$ & $\begin{array}{c}26.90^{\mathrm{a}} \pm 0.98 \\
(16)\end{array}$ & $\begin{array}{c}5.46^{\mathrm{bc}} \pm 0.60 \\
(13)\end{array}$ & $\begin{array}{c}8.27^{\mathrm{bc}} \pm 0.80 \\
(13)\end{array}$ & $\begin{array}{c}4.67^{\mathrm{ab}} \pm 0.40 \\
(12)\end{array}$ & $\begin{array}{c}75.41^{\mathrm{a}} \pm 7.15 \\
(12)\end{array}$ \\
\hline & $\begin{array}{c}154 / 148 \\
(6)\end{array}$ & $\begin{array}{c}17.10^{\mathrm{a}} \pm 2.35 \\
\text { (6) }\end{array}$ & $\begin{array}{c}26.41^{\mathrm{a}} \pm 1.24 \\
(6)\end{array}$ & $\begin{array}{c}4.00^{\mathrm{c}} \pm 0.63 \\
(5)\end{array}$ & $\begin{array}{c}6.28^{c} \pm 0.84 \\
(5)\end{array}$ & $\begin{array}{c}3.60^{\mathrm{b}} \pm 0.40 \\
(5)\end{array}$ & $\begin{array}{c}50.40^{\mathrm{b}} \pm 1.42 \\
(5)\end{array}$ \\
\hline & $\begin{array}{c}154 / 142 \\
(8)\end{array}$ & $\begin{array}{c}15.16^{\mathrm{a}} \pm 1.51 \\
\text { (8) }\end{array}$ & $\begin{array}{c}28.35^{\mathrm{a}} \pm 1.18 \\
(8)\end{array}$ & $\begin{array}{c}7.38^{\mathrm{a}} \pm 0.92 \\
(8)\end{array}$ & $\begin{array}{c}11.12^{\mathrm{a}} \pm 1.51 \\
(8)\end{array}$ & $\begin{array}{c}5.13^{\mathrm{a}} \pm 0.61 \\
(8)\end{array}$ & $\begin{array}{c}81.16^{\mathrm{a}} \pm 11.10 \\
(8)\end{array}$ \\
\hline & $\begin{array}{c}148 / 148 \\
(33)\end{array}$ & $\begin{array}{c}16.94^{\mathrm{a}} \pm 0.80 \\
(33)\end{array}$ & $\begin{array}{c}28.04^{\mathrm{a}} \pm 0.67 \\
(33)\end{array}$ & $\begin{array}{c}5.84^{\mathrm{ab}} \pm 0.33 \\
(32)\end{array}$ & $\begin{array}{c}9.08^{\mathrm{ab}} \pm 0.59 \\
(32)\end{array}$ & $\begin{array}{c}5.20^{\mathrm{a}} \pm 0.30 \\
(30)\end{array}$ & $\begin{array}{c}81.68^{\mathrm{a}} \pm 4.54 \\
(30)\end{array}$ \\
\hline & $\begin{array}{c}142 / 142 \\
(39)\end{array}$ & $\begin{array}{c}16.27^{\mathrm{a}} \pm 0.57 \\
(39)\end{array}$ & $\begin{array}{c}29.17^{\mathrm{a}} \pm 0.65 \\
\text { (39) }\end{array}$ & $\begin{array}{c}6.34^{\mathrm{ab}} \pm 0.24 \\
(32)\end{array}$ & $\begin{array}{c}9.74 \mathrm{ab} \pm 0.33 \\
(32)\end{array}$ & $\begin{array}{c}5.73^{\mathrm{a}} \pm 0.26 \\
(30)\end{array}$ & $\begin{array}{c}93.90^{\mathrm{a}} \pm 3.86 \\
(30)\end{array}$ \\
\hline & $\begin{array}{l}\text { Mean } \\
(102)\end{array}$ & $\begin{array}{c}16.76 \pm 0.41 \\
(102)\end{array}$ & $\begin{array}{c}28.22 \pm 0.39 \\
(102)\end{array}$ & $\begin{array}{c}6.00 \pm 0.20 \\
(90)\end{array}$ & $\begin{array}{l}9.22 \pm 0.31 \\
(90)\end{array}$ & $\begin{array}{c}5.21^{\mathrm{a}} \pm 0.17 \\
(85)\end{array}$ & $\begin{array}{c}83.22 \pm 2.76 \\
(85)\end{array}$ \\
\hline \multirow{5}{*}{ DXMit187 } & $\begin{array}{c}146 / 146 \\
(4)\end{array}$ & $\begin{array}{c}16.52^{\mathrm{a}} \pm 2.07 \\
(4)\end{array}$ & $\begin{array}{c}25.70^{\mathrm{a}} \pm 0.75 \\
\text { (4) }\end{array}$ & $\begin{array}{c}5.00^{\mathrm{a}} \pm 1.00 \\
(3)\end{array}$ & $\begin{array}{c}7.32^{\mathrm{a}} \pm 1.38 \\
\text { (3) }\end{array}$ & $\begin{array}{c}4.00^{\mathrm{a}} \pm 0.00 \\
\text { (2) }\end{array}$ & $\begin{array}{c}64.61^{\mathrm{a}} \pm 1.21 \\
\text { (2) }\end{array}$ \\
\hline & $\begin{array}{c}146 / 134 \\
(11)\end{array}$ & $\begin{array}{c}16.70^{\mathrm{a}} \pm 1.83 \\
(11)\end{array}$ & $\begin{array}{c}29.26^{\mathrm{a}} \pm 1.32 \\
(11)\end{array}$ & $\begin{array}{c}6.40^{\mathrm{a}} \pm 0.67 \\
(10)\end{array}$ & $\begin{array}{c}9.65^{\mathrm{a}} \pm 1.01 \\
(10)\end{array}$ & $\begin{array}{c}5.44^{\mathrm{a}} \pm 0.60 \\
(9)\end{array}$ & $\begin{array}{c}89.33^{\mathrm{a}} \pm 6.93 \\
(9)\end{array}$ \\
\hline & $\begin{array}{c}134 / 134 \\
(27)\end{array}$ & $\begin{array}{c}16.71^{\mathrm{a}} \pm 0.84 \\
(27)\end{array}$ & $\begin{array}{c}28.36^{\mathrm{a}} \pm 0.73 \\
(27)\end{array}$ & $\begin{array}{c}6.33^{\mathrm{a}} \pm 0.36 \\
(24)\end{array}$ & $\begin{array}{c}9.46^{\mathrm{a}} \pm 0.51 \\
(24)\end{array}$ & $\begin{array}{c}5.70^{\mathrm{a}} \pm 0.34 \\
(23)\end{array}$ & $\begin{array}{c}87.71^{\mathrm{a}} \pm 5.09 \\
(23)\end{array}$ \\
\hline & $\begin{array}{c}126 / 126 \\
(60)\end{array}$ & $\begin{array}{c}16.80^{\mathrm{a}} \pm 0.49 \\
(60)\end{array}$ & $\begin{array}{c}28.14^{\mathrm{a}} \pm 0.51 \\
\quad(60)\end{array}$ & $\begin{array}{c}5.83^{\mathrm{a}} \pm 0.26 \\
(53)\end{array}$ & $\begin{array}{c}9.14^{\mathrm{a}} \pm 0.44 \\
(53)\end{array}$ & $\begin{array}{c}5.00^{\mathrm{a}} \pm 0.21 \\
(51)\end{array}$ & $\begin{array}{c}80.84^{\mathrm{a}} \pm 3.75 \\
(51)\end{array}$ \\
\hline & $\begin{array}{l}\text { Mean } \\
(102)\end{array}$ & $\begin{array}{c}16.76 \pm 0.41 \\
(102)\end{array}$ & $\begin{array}{c}28.22 \pm 0.39 \\
(102)\end{array}$ & $\begin{array}{l}6.00 \pm 0.20 \\
(90)\end{array}$ & $\begin{array}{c}9.22 \pm 0.31 \\
(90)\end{array}$ & $\begin{array}{c}5.21 \pm 0.17 \\
(85)\end{array}$ & $\begin{array}{c}83.22 \pm 2.76 \\
(85)\end{array}$ \\
\hline
\end{tabular}

*Means with the same superscript are not significantly $(\mathrm{p}<0.05)$ different.

fitness traits was less detrimental in males as compared to females. This further indicates that tolerance power of males to detrimental effect of inbreeding was more as compared to females. It is advised that microsatellite genotyping spanning whole genome might be more reliable for genetic characterization of an inbred strain.

\section{ACKNOWLEDGEMENT}

The authors are grateful to the Director, ICAR-Indian Veterinary Research Institute, Izatnagar, Bareilly, (U. P.); and the Director, Indian Council of Medical Research, New Delhi, India for providing the essential facilities and financial assistance to carry out the research work, respectively.

\section{REFERENCES}

Casellas J (2011) Inbred mouse strains and genetic stability: a review. Animal 5: 1-7.
Danneman PJ, Suckow MA, Brayton C (2012) The laboratory mouses. CRC Press.

Eppig JT (2007) Mouse strain and genetic nomenclature: an abbreviated guide, 79-98. In: Fox JG, Davisson MT, Quimby FW, Barthold SW, Newcomer CE et al. (editors) The mouse in biomedical research. Elsevier, London.

Gulcher J (2012) Microsatellite markers for linkage and association studies. Cold Spring Harbor Protocols 2012(4): pdb-top068510.

Holt M, Nicholas FW, James JW, Moran C, Martin IC (2004) Development of a highly fecund inbred strain of mice. Mamm Genome 15(12): 951-959.

Kaushal S (2019) Genetic analysis of inbred Swiss albino mice of different filial generations. Ph.D. Thesis submitted in Indian Veterinary Research Institute, Bareilly, India. 
Assessing the impact of sex-specific microsatellite variants on phenomics...

Leclercq GC, Rozenfeld FM (2001) A permanent marking method to identify individual small rodents from birth to sexual maturity. J Zool 254(2): 203-206.

Li B, Qing T, Zhu J, Wen Z, Yu Y et al. (2017) A comprehensive mouse transcriptomic body map across 17 tissues by RNA-seq. Sci Rep 7(1): 4200.

Lukas FK, Donald MW (2002) Inbreeding in wild populations. Ecol Evol 17(5): 230-234.

Nomura T, Esaki K, Tomita T (1984) ICLAS Manual for genetic monitoring of inbred mice. University of Tokyo Press.

Selvaggi M, Darioa C, Peretti V, Ciotolac F, Carnicella D et al. (2010). Inbreeding depression in Leccese sheep. Small Rumin Res 89(1): 42-46.

Sommer SS, Ketterling RP (1994) How precisely can data from transgenic mouse mutation-detection systems be extrapolated to humans? lesions from the human factor IX gene. Mutat Res 307: 517-531.

Tarang M (2018) Phenotypic and genetic characterization of outbred and F1 inbred Swiss albino strain of mice. Ph.D. Thesis submitted in Indian Veterinary Research Institute, Bareilly, India.
Tautz D (1989) Hypervariability of simple sequences as a general source for polymorphic DNA markers. Nucleic Acids Res 17: 6463-6471.

White JM (1972) Inbreeding effects upon growth and maternal ability in laboratory mice. Genetics 70(2): 307-317.

Yeh FC (1999) POPGENE (version 1.3. 1). Microsoft window-bases freeware for population genetic analysis. http:// www. ualberta. ca/ fyeh/.

Yue F, Cheng Y, Breschi AA (2014) Comparative encyclopedia of DNA elements in the mouse genome. Nature 515: 355-364.

Zhang X, Zhu Z, Huang Z, Tan P, Ma RZ (2007) Microsatellite genotyping for four expected inbred mouse strains from KM mice. J Genet Genomics 34(3): 214-222.

Zheng-Bradley X, Rung J, Parkinson H, Brazma A (2010) Large scale comparison of global gene expression patterns in human and mouse. Genome Biol 11: R124.

Zuo B, Du X, Zhao J, Yang H, Wang Cet al. (2012) Analysis of microsatellite polymorphism in inbred knockout mice. PloS one 7(4): 34555.

*Cite this article as: Saini BL, Kumar P, Kumar A, Tarang M, Sachan S, Mehrotra A, Kaushal S, Chauhan A, Prakash J (2021) Assessing the impact of sex-specific microsatellite variants on phenomics of inbred Swiss albino mice. Explor Anim Med Res 11(2): 198-204. DOI : 10.52635/eamr/11.2.198-204. 